\title{
EVAluation OF Limiting NUTRIENTS AND TROPHIC State FOR SELECTEd PONDS IN THE NATIONAL ELK REFUGE
}

\author{
RYAN COLE $\uparrow$ WOODRUFF MILLER \\ DEPARTMENT OF CIVIL AND ENVIRONMENTAL ENGINEERING \\ BRIGHAM YOUNG UNIVERSITY $\uparrow \mathrm{PROVO} \uparrow \mathrm{UT}$
}

\section{$\downarrow$ EXECUTIVE SUMMARY}

During the years 2000 and 2001 several water samples were taken and observations were made in order to assess the limiting nutrients and the trophic state of the water at five locations in the National Elk Refuge near Jackson, Wyoming. These five locations were: Pond by Hay Barn, Pond by Gravel Pit, Pond by Miller House, Flat Creek (at bridge) in Elk Refuge, and Elk Refuge Outlet (Flat Creek at City Bridge).

Nitrogen and phosphorus measurements were taken and the nitrogen-phosphorus $(\mathrm{N}: \mathrm{P})$ ratio was determined for each sample. The N:P ratios for the ponds were high which indicates that phosphorus was generally the limiting nutrient and the $\mathrm{N}: \mathrm{P}$ ratios for Flat Creek were low which indicates that nitrogen was limiting.

Along with phosphorus, chlorophyll-a measurements were also taken, and these data were used in the Carlson Model in order to determine the trophic state. The Carlson results indicate that the ponds are classified as oligotrophic to slightly mesotrophic (good water quality) and Flat Creek is classified as mesotrophic. However, based on the phosphorus measurements only, without the chlorophyll-a, the ponds are classified as mesotrophic and the Creek is classified as eutrophic (poor water quality).
With the exception of the Elk Refuge Outlet (Flat Creek), which is eutrophic, there are no serious identified areas of water quality concern with regards to eutrophication in the Elk Refuge. These results should be useful in comparing with past and future studies in order to determine the effects of animal and human interaction on these waters.

\section{$\uparrow \quad$ INTRODUCTION}

The purpose of this study was to perform a benchmark trophic state survey for comparison to future evaluations and to identify possible areas of concern. Lakes and ponds were sampled for phosphorus and chlorophyll-a concentrations. From these concentrations, the trophic states were estimated from each water sample. Trophic states may range from oligotrophic to hyper-eutrophic. The greater the trophic state, the greater the level of eutrophication that has taken place. As lakes advance in the eutrophication process, water quality generally decreases.

Eutrophication occurs naturally, but is often accelerated by human influence. It is caused by the increase of nutrients, such as nitrogen and phosphorus, in the water. This results in algae blooms, waterweed growth, murky water and greater populations of trash fish. Hyper-eutrophic lakes are likely to contain water with undesirable tastes and odors. 


\section{Nitrogen}

Nitrogen is a common cellular element of living matter and essential to the growth of algae and other forms of aquatic life. It is one of the most important nutrients effecting eutrophication. Although most of the nitrogen in aquatic ecosystems is present as the gas $\mathrm{N}_{2}$, the in-lake nitrogen measured in this study is in the form of nitrate $\left(\mathrm{NO}_{3}{ }^{-}\right)$ nitrite $\left(\mathrm{NO}_{2}^{-}\right)$, or ammonia $\left(\mathrm{NH}_{4}{ }^{+}\right)$. These forms of nitrogen are most available for aquatic life. Nitrate is the most common form of biologically available nitrogen. It passes from rain to rivers and lakes, where algae take up much of it. It is then used by algae for growth and later deposited in the sediments. Nitrogen in algae eaten by zooplankton and insect larvae is excreted as ammonia, which is nitrified and recycled back to algae in the summer. Nitrate not used up by algae may be transformed by denitrifying bacteria into gaseous nitrogen (Horne, 1994).

When nitrogen is limiting growth, nitrogen is sometimes supplemented by nitrogen fixation. In this process, nitrogen gas is transformed into ammonia by an enzyme. It occurs in only a few genera of bacteria and blue-green algae. When phosphorus supplies and other conditions are favorable, nitrogen fixation can be a major source of new, usable nitrogen. Thus it can cause lake eutrophication to accelerate even when other nitrogen sources are very limited. Summer or autumn blooms of nitrogen-fixing blue-green algae are common in most eutrophic lakes. In oligotrophic lakes, however, nitrogen fixation plays a minor role (Horne, 1994).

The major source of nitrogen for lakes is the nitrate in rainfall and dry precipitation on their watersheds. Much nitrate passes directly from the rain in the watershed to the lake via streams or falls directly on the lake. When rain soaks into the ground, nitrate moves freely through soils to the lake. Lakes can have considerable nitrate input from groundwater, especially if the water is contaminated with agricultural nitrate (Horne, 1994).

Ammonia, often present as ammonium, is also readily taken up by algae. It is more reactive than nitrate, and thus has a greater tendency to bond to clay particles or organic matter in the soil. Although ammonia is rapidly taken up by algae, it persists in small quantities because it is also the major excretory product of aquatic animals. If present in concentrations too great, ammonium can be toxic to animal life. For this to happen, however, pollution would have to be the cause. Ammonia in most lakes and streams is generally well below 0.1 $\mathrm{mg} / \mathrm{liter}$. The major source of ammonia is from inflowing rivers, precipitation, atmospheric dust, or nitrogen fixation (Horne, 1994).

\section{Phosphorus}

Phosphorus is another key nutrient involved in the eutrophication process. It is an essential component of nucleic acids and plays an integral role in the metabolism of all forms of life. It is the most common growth-limiting element in fresh water. Although orthophosphate is the only form of phosphorus that is biologically available, phosphorus is usually measured in lakes as total phosphorus. This is because total phosphorus is found to correlate well with orthophosphate (Horne, 1994).

The initial source of phosphorus is weathering of phosphate-containing rocks. As these rocks are weathered into soils, phosphate becomes electrostatically bound to the molecular lattice of the soil particles. Consequently, it is not easily leached out in soluble forms. Because phosphorus tends to remain bound to soil particles, drainage from eroded soils carries higher amounts of phosphorus than from vegetated soils. Similarly, surface runoff, with its relatively large content of soil particles, yields higher concentrations of total phosphorus than infiltration water (Harper, 1992).

Phosphorus enters lakes as a mixture of dissolved and particulate inputs primarily from streams and rivers. Particulates may release phosphate and organic phosphates to solution after entering the lake. Compounds of phosphorus may be hydrolyzed to orthophosphate, which is the only form that can be taken up by bacteria, algae, and plants. Particulate phosphorus may be deposited in the bottom sediments, where much of it is acted upon by micro-bacteria and ultimately converted into dissolved orthophosphate (Correll, 1998).

Lakes usually retain phosphorus fairly efficiently in the bottom sediments. In oligotrophic lakes, sufficient oxygen levels near the lake bottom helps phosphorus to remain stored in the sediments. In eutrophic lakes, however, anoxic conditions near the lake bottom may promote the release of phosphorus from the sediments into the water column (Correll, 1998), thereby accelerating the eutrophication process.

In most lakes, phosphorus is present in more limiting amounts than nitrogen. When the input of phosphorus into lakes is increased due to human activity, the phosphorus is efficiently retained. This leads to higher productivity, increased decomposition 
of organic matter, and decreased levels of oxygen, which kills fish and changes the species composition of the lake.

\section{The Nitrogen-Phosphorus Ratio}

Nitrogen and phosphorus are the elements most important for growth of living organisms. While there are many nutrients necessary for algae growth, nitrogen and/or phosphorus tend to be present in the most limiting amounts. This means that the quantity of nitrogen, phosphorus, or both will most likely limit the maximum algal biomass that can grow in the lake. The assessment of the limiting nutrient is important, because control of the limiting nutrient can inhibit algal growth. The relative proportions of nitrogen and phosphorus can change seasonally, as demonstrated by the nitrogenphosphorus $(\mathrm{N}: \mathrm{P})$ ratios of the lakes studied in this report.

Practical experience suggests that concentrations of biologically available phosphorus of less than $5 \mu \mathrm{g} / 1$ indicate potential phosphorus limitation, while concentrations of biologically available nitrogen less than $20 \mu \mathrm{g} / 1$ suggest nitrogen limitation. Both phosphorus and nitrogen may be limiting if neither boundary value is exceeded (Ryding, 1989).

In addition to the consideration of boundary values, the nitrogen-phosphorus (N:P) ratio is commonly used to determine whether nitrogen or phosphorus is the limiting nutrient. This ratio is based on the relative mass of nitrogen to phosphorus in the algae's cell material, which is about 7 . The application of this ratio is based upon the assumption that nutrient consumption and cell composition have the same ratio of nitrogen to phosphorus in mass (Ryding, 1989). In theory, an N:P ratio less than 7 implies that nitrogen is more likely to be limiting. Conversely, an N:P ratio greater than 7 implies that phosphorus is more likely to be limiting ( $\mathrm{Li}, 1995)$. The value of 7 should not be applied too strictly, however. In the laboratory it has been found that the cellular content of nitrogen and phosphorus in algae can vary, indicating that the ratio at which the algae use these nutrients may also vary to some degree. In addition, different species of algae may be limited by different nutrients simultaneously in the same lake. Even so, wide ranges in algal N:P ratios are not usually found in natural water bodies (Ryding, 1989). In practice, phosphorus is considered limiting if the N:P ratio is greater than 10 , nitrogen is considered limiting if the $\mathrm{N}: \mathrm{P}$ ratio is less than 5 , and both phosphorus and nitrogen are considered limiting if the $\mathrm{N}: \mathrm{P}$ ratio is between 5 and $10(\mathrm{Li}, 1995)$.

The N:P ratio in a water body can be useful for assessing the types of algae likely to exist under different nutrient conditions. Studies have reported that low N:P ratios appear to favor blue-green algal dominance, while such algae are rare when the N:P ratio reaches 29 . This is due to the fact that bluegreen algae dominates nitrogen-fixation, in which nitrogen can be obtained from the atmosphere under nitrogen limiting conditions. Blue-green algae are the most noxious species of algae, particularly those which cause surface scums. Green algae tend to replace the problematic blue-green algae as the N:P ratio increases (Ryding, 1989).

The nitrogen-phosphorus ratios have been calculated for the water samples considered in this study. Nitrogen levels were calculated by adding nitrate, nitrite, and ammonia $\mathrm{N}$ together. Where ratios are between 5 and 10, both phosphorus and nitrogen can be considered limiting. Nitrogen can be considered limiting where ratios are less than 5 . Phosphorus can be considered limiting where ratios are greater than 10 .

\section{Modeling}

The Carlson Model, the Vollenweider Model, and the Larsen-Mercier Model were used to determine the trophic state of the selected lakes in Yellowstone National Park. Only the Carlson Model was used to determine the trophic state of the selected ponds in the National Elk Refuge. The Carlson Model takes into account transparency and in-lake phosphorus and chlorophyll-a concentrations. Chlorophyll-a measures algal biomass directly and in-lake total phosphorus is an indicator of nutrient availability to drive algal growth. Transparency can also indicate algal biomass, but was not measured in this study.

\section{$\uparrow \quad$ MeTHODS}

Samples were taken in 0.5 liter nalgene bottles and fixed with $2 \mathrm{ml} \mathrm{1:7} \mathrm{sulfuric} \mathrm{acid.} \mathrm{Inlet}$ stream grab samples were taken with care so as to not disturb bottom sediments. In-lake and inlet samples were analyzed for total phosphorus (TP), while the in-lake samples were also analyzed for chlorophyll-a. Phosphorus analyses were conducted using the standard EPA No. 365.2 automated ascorbic acid colormetric method. Spectrophotometric chlorophyll 
analyses were conducted using Standard Methods No. 10200 H. Samples were analyzed by personnel at the Utah State Health Department - Division of Laboratory Services. A summary of lab results is listed in Appendix A.

\section{$\uparrow \quad$ RESULTS}

Water samples were taken from five locations in the National Elk Refuge shown on Map E1. Sampling was done between the months of June 2000 and August 2001. For this study, the locations shown on the map are named: Pond by Hay Barn, Pond by Gravel Pit, Pond by Miller House, Flat Creek in Elk Refuge, and Elk Refuge Outlet (Flat Creek at City Bridge). The last two locations are not ponds, but are creek segments at which the water flows very slowly.

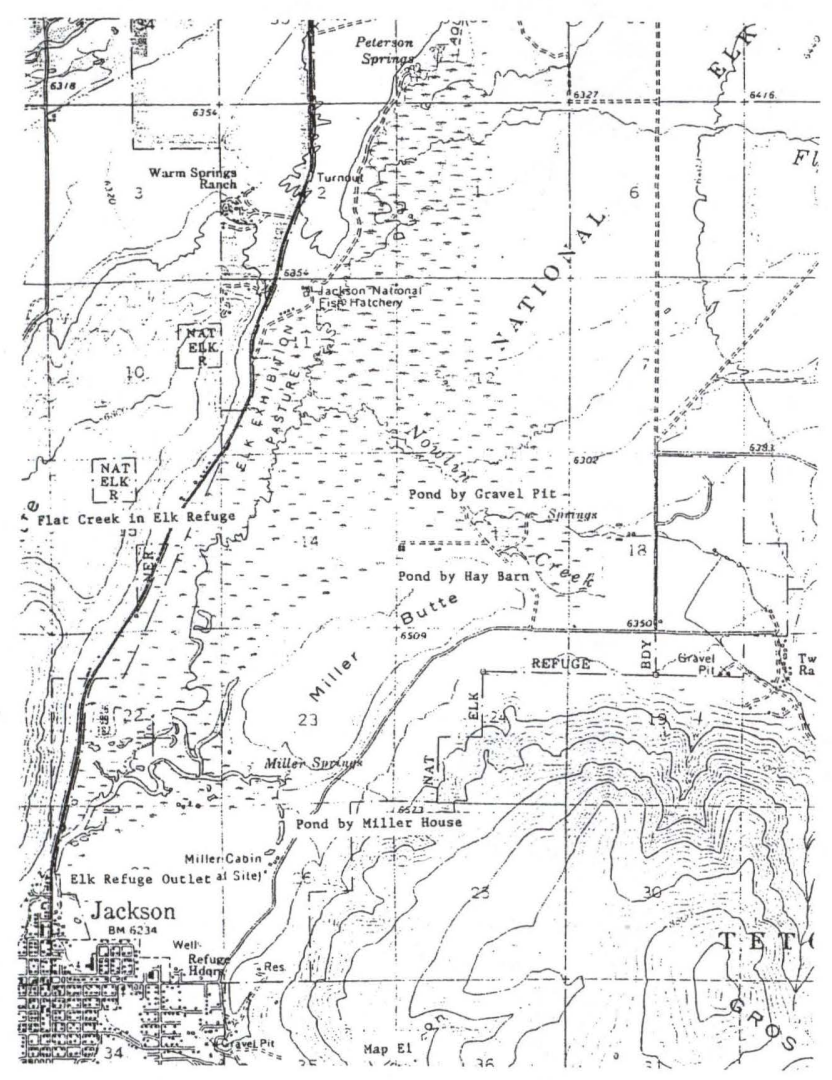

N:P Ratio Results

Table E1 lists the N:P ratios for the lakes studied at the Elk Refuge. As indicated in the table, the N:P ratio averages are highest at Pond by Gravel Pit, Pond by Hay Barn and Pond by Miller House. At these locations, phosphorus is considered limiting for most of the months sampled. Flat Creek in Elk Refuge and Elk Refuge Outlet have the lowest N:P ratio averages. At these locations, nitrogen is considered the limiting nutrient for most of the months sampled.

\begin{tabular}{|c|c|c|c|c|c|}
\hline \multicolumn{7}{|c|}{ Table E1: N:P Ratios for Elk Refuge Samples } \\
\hline \multicolumn{2}{|c|}{$\begin{array}{c}\text { Pond by } \\
\text { Hay Bam }\end{array}$} & \multicolumn{2}{c|}{$\begin{array}{c}\text { Pond by } \\
\text { Gravel Pit }\end{array}$} & \multicolumn{2}{c|}{$\begin{array}{c}\text { Pond by } \\
\text { Miller House }\end{array}$} \\
\hline Date & Ratio & Date & Ratio & Date & Ratio \\
\hline Oct-00 & 10.3 & Oct-00 & 11.1 & Oct-00 & 10.3 \\
\hline Mar-01 & 9.17 & Mar-01 & 6.4 & Mar-01 & 6.3 \\
\hline May-01 & 6.5 & May-01 & 7.14 & May-01 & 4.8 \\
\hline Jun-01 & 7.5 & Jun-01 & 10.7 & Jun-01 & 10.7 \\
\hline Jul-01 & 13.6 & Jul-01 & 15 & Jul-01 & 6.25 \\
\hline Aug-01 & 11.5 & Aug-01 & 11.5 & Aug-01 & 13.6 \\
\hline Avg: & 9.8 & Avg: & 10.3 & Avg: & 8.7 \\
\hline
\end{tabular}

At Pond by Hay Barn, Pond by Gravel Pit and Pond by Miller House, N:P ratios tend to be low during spring and early summer and high during summer and fall. This is because phosphorus levels tend to be higher in the early months than in the later months of the year. This decrease in phosphorus levels may be due to the uptake of phosphorus by algae throughout the summer.

At Flat Creek in Elk Refuge for the month of October, the N:P ratio was only 0.95 . This was due to an unusually high amount of phosphorus, measured at $158 \mathrm{ppb}$. The high phosphorus concentrations likely come from soil eroded by the creek.

\section{Modeling Results}

The results of the Elk Refuge water sample analyses were plotted on the Carlson Model, given as Figures E1-E5. Plotted results led to trophic state classifications as stated in the following paragraphs and listed in Table E2. Table E2 shows trophic state classifications for both phosphorus alone and phosphorus with chlorophyll-a averaged in. Many samples were measured to have $0 \mathrm{mg} / \mathrm{L}$ of chlorophyll-a. The reason for this is unknown. In most cases, chlorophyll-a measurements caused the trophic state to be much less eutrophic than phosphorus measurements alone. Abnormally high levels of phosphorus were found during the month of March. This is likely due to the large numbers of elk that were in the area during that time. 


\begin{tabular}{|l|l|l|}
\hline Table E2: Trophic States According to the Carlson Model \\
\hline \hline Lake & $\begin{array}{l}\text { Phosphorus } \\
\text { Only }\end{array}$ & $\begin{array}{l}\text { Phosphorus } \\
\text { \& Chlorophyll }\end{array}$ \\
\hline Pond by Hay Barn & Mesotrophic & Oligotrophic \\
\hline Pond by Gravel Pit & Mesotrophic & Slightly Meso. \\
\hline Pond by Miller House & Strongly Meso. & Slightly Meso. \\
\hline Flat Creek in Elk Refuge & Eutrophic & Slightly Meso. \\
\hline Elk Refuge Outlet & Slightly Eutro. & Mesotrophic \\
\hline
\end{tabular}

\section{Pond by Hay Barn}

Figure E1 indicates that the pond by hay barn is oligotrophic according to the Carlson Model when both phosphorus and chlorophyll-a are considered (top row). For phosphorus alone (bottom row), trophic state indices for all months spread throughout the mesotrophic range. In March the phosphorus level was strongly mesotrophic. It then decreased in small increments through May and June. In July, the phosphorus fell to only slightly mesotrophic and in August it increased a little. October's measurement (though taken the previous year) was greater still.

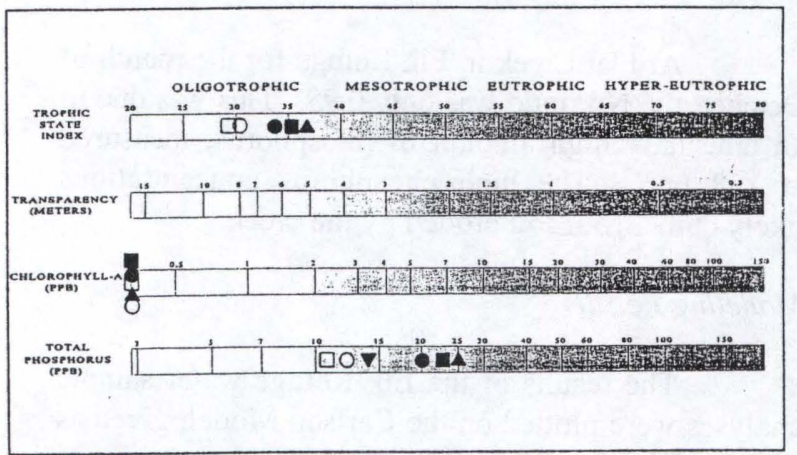

Figure E1 Carlson's Trophic State Indices for Pond by Hay Barn

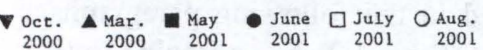

\section{Pond by Gravel Pit}

The pond by gravel pit can be considered slightly mesotrophic overall, as shown in Figure E2 (top row). A look at phosphorus levels alone (bottom row), however, would lead to a classification of mesotrophic. Chlorophyll-a measurements bring down the trophic state indexes for all the months sampled. The phosphorus measurement for the month of March reached $36 \mathrm{ppb}$, in the slightly eutrophic zone. During the months of May, June, and July the phosphorus level was measured at 21 $\mathrm{ppb}, 14 \mathrm{ppb}$, and $10 \mathrm{ppb}$, respectively, showing a steady decrease in phosphorus levels from March through July.

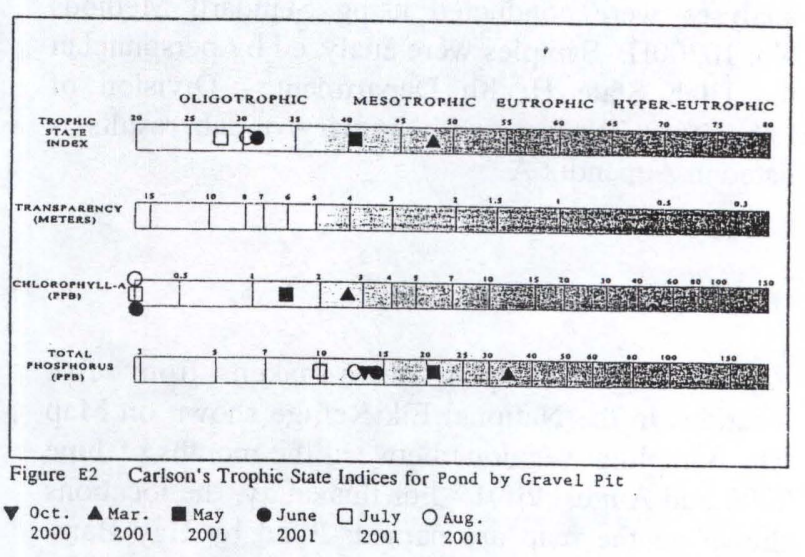

\section{Pond by Miller House}

Figure E3 indicates that the pond by Miller House is slightly mesotrophic (top row) according to the Carlson Model. Phosphorus measurements alone, however, indicate a trophic state of strongly mesotrophic (bottom row). March is the most eutrophic, probably due to the presence of elk. Otherwise, there doesn't seem to be a pattern correlating trophic state with time of year.

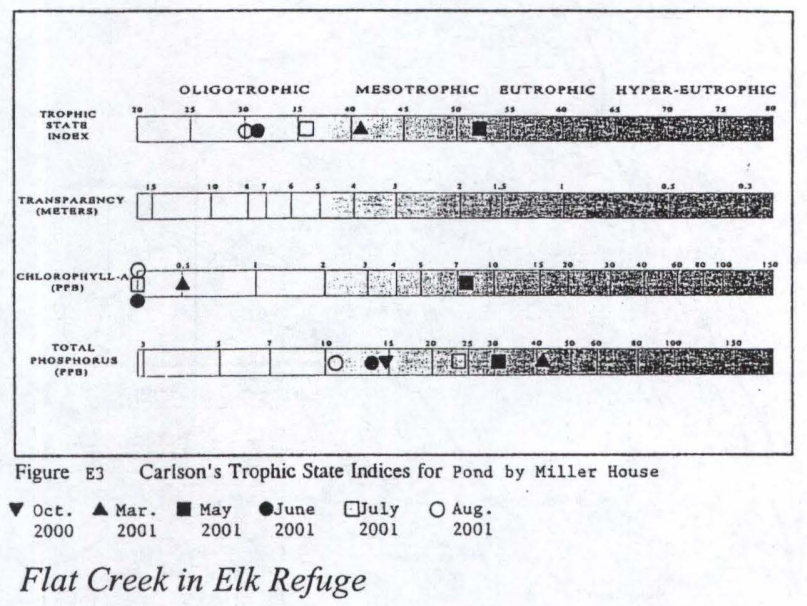

Trophic state evaluations based on samples taken from Flat Creek within the Elk Refuge are considered less reliable because the Carlson Model is meant to be used with ponds and lakes, not with creeks. Even so, these samples were taken from a slow-flowing reach of Flat Creek and might provide some helpful information. Figure E4 indicates that this location is eutrophic based on phosphorus measurements alone (bottom row), and slightly mesotrophic when the chlorophyll-a measurements are taken into account (top row). The chlorophyll-a measurements may be misleading due to the fact that the samples were taken from a creek rather than a standing water body. During the months of October 
and March, phosphorus levels are hyper-eutrophic and strongly eutrophic, respectively. Phosphorus levels are much lower during the summer months of May through August.

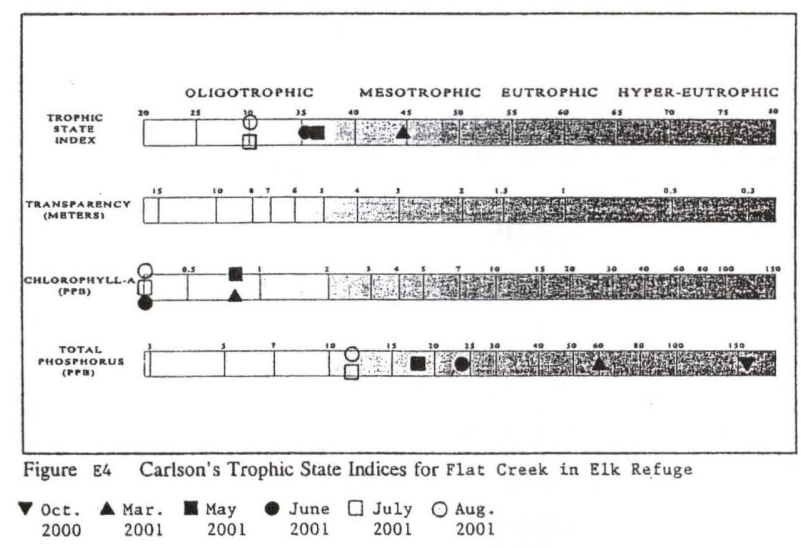

\section{Elk Refuge Outlet}

Samples taken from the Elk Refuge Outlet are also taken from a running body of water rather than a standing body. However, the water flows very slowly at this location and the results are meaningful. With phosphorus levels alone, the samples average slightly eutrophic (see Figure E5). When chlorophyll-a measurements are taken into account, the trophic state is mesotrophic. The results for June 2000 are very close to those for June 2001, showing a consistent yearly cycle. Also, August 2000 and July 2001 have very close phosphorus measurements. Similar to the results from Flat Creek in Elk Refuge, both chlorophyll-a and phosphorus levels are higher in March and October than the rest of the year.

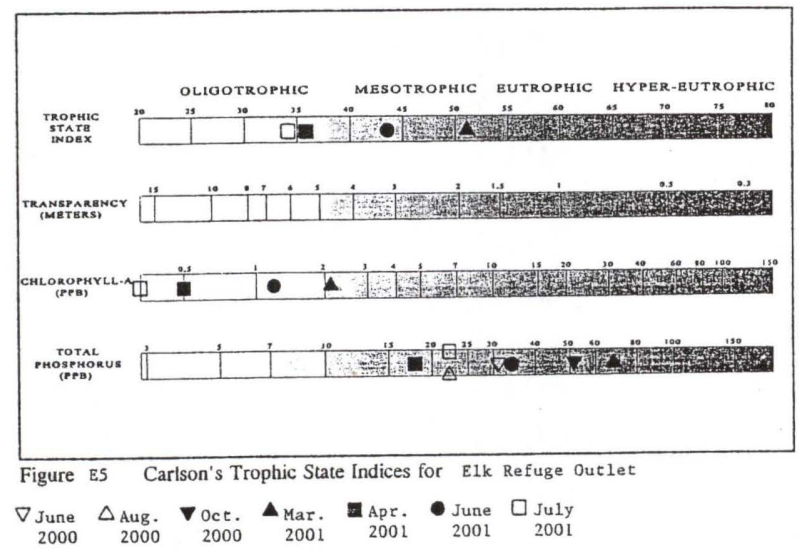

\section{$\downarrow \quad$ CONCLUSIONS}

The N:P ratios for the samples taken at the National Elk Refuge indicate that phosphorus is the limiting nutrient for Pond by Hay Barn, Pond at Gravel Pit, and Pond by Miller House for more than half of the months sampled. Each pond has an average $\mathrm{N}: \mathrm{P}$ ratio approaching 10 or greater, showing a general tendency towards phosphorus limitation. The N:P ratios for Flat Creek in Elk Refuge and Elk Refuge Outlet approach nitrogen limitation. The low $\mathrm{N}: \mathrm{P}$ ratios are likely a result of phosphorus uptake due to erosion.

On the Carlson Model, locations were assigned trophic states under phosphorus alone and phosphorus and chlorophyll together. In nearly all cases, chlorophyll concentrations lowered the trophic state to mesotrophic or below. When phosphorus concentrations are considered alone, Pond by Miller House is classified as strongly mesotrophic, while Pond by Hay Barn and Pond by Gravel Pit are both classified as mesotrophic. Again considering phosphorus alone, Flat Creek in Elk Refuge and Elk Refuge Outlet are classified as eutrophic and slightly eutrophic, respectively.

Classifications for these two locations may be less accurate than the others since the Carlson Model was not designed for slow moving creeks, but for ponds and lakes. With the exception of Elk Refuge Outlet (Flat Creek), which is eutrophic, there are no identified areas of concern due to eutrophication. These results should be useful in comparing with past and future studies in order to determine the effects of human and animal interaction on these ponds.

\section{$\downarrow$ Literature Cited}

Correll, D.L. (1998). The role of phosphorus in the eutrophication of receiving waters: a review. Journal of Environmental Quality, Madison, WI, 27 (2), 261-266.

Harper, D. (1992). Eutrophication of freshwater. Chapman and Hall, New York, NY, 36-53.

Horne, A.J. and Goldman, C.R. (1994). Limnology. McGraw-Hill, Inc., New York, NY, 133150.

Li, C.C. (1995). Eutrophication of two lakes in Kinmen Island (Taiwan). Chemistry and Ecology, London, England, 3 (1), 61-63.

Ryding, S.O. and Rast,W. (1989). The control of eutrophication of lakes and reservoirs. The Partheon Publishing Group, New Jersey, 4958. 


\section{Appendix A}

Summary of Lab Results

\begin{tabular}{|c|c|c|c|c|c|}
\hline Location & Date & $\begin{array}{l}\text { Phos. } \\
\text { (mg/L) }\end{array}$ & $\begin{array}{c}\mathrm{NO}+\mathrm{NO} 3, \mathrm{~N} \\
(\mathrm{mg} / \mathrm{L})\end{array}$ & $\begin{array}{r}\text { Ammonia } N \\
(\mathrm{mg} / \mathrm{L})\end{array}$ & $\begin{array}{l}\text { Chlorophyll-a } \\
\text { (ppb) }\end{array}$ \\
\hline \multirow[t]{6}{*}{ Pond by Hay Barn } & $10 / 6 / 00$ & 0.0145 & 0.1 & $<0.05$ & \\
\hline & $3 / 17 / 01$ & 0.024 & .017 & .05 & 0 \\
\hline & $5 / 1 / 01$ & 0.023 & $<0.1$ & $<0.05$ & 0 \\
\hline & $6 / 20 / 01$ & 0.02 & $<0.1$ & $<0.05$ & 0 \\
\hline & $7 / 13 / 01$ & 0.011 & $<0.1$ & $<0.05$ & 0 \\
\hline & $8 / 21 / 01$ & 0.013 & 0.1 & $<0.05$ & 0 \\
\hline \multirow[t]{6}{*}{ Pond by Gravel Pit } & $10 / 6 / 00$ & 0.0135 & 0.1 & $<0.05$ & \\
\hline & $3 / 17 / 01$ & 0.036 & 0.18 & $<0.05$ & 2.7 \\
\hline & $5 / 1 / 01$ & 0.021 & $<0.1$ & $<0.05$ & 1.4 \\
\hline & $6 / 20 / 01$ & 0.014 & $<0.1$ & $<0.05$ & 0 \\
\hline & $7 / 13 / 01$ & 0.01 & $<0.1$ & $<0.05$ & 0 \\
\hline & $8 / 21 / 01$ & 0.013 & 0.1 & $<0.05$ & 0 \\
\hline \multirow[t]{6}{*}{ Pond by Miller House } & $10 / 6 / 00$ & 0.0145 & 0.1 & $<0.05$ & \\
\hline & $3 / 17 / 01$ & 0.041 & 0.21 & $<0.05$ & 0.5 \\
\hline & $5 / 1 / 01$ & 0.031 & $<0.1$ & $<0.05$ & 8.3 \\
\hline & $6 / 20 / 01$ & 0.014 & $<0.1$ & $<0.05$ & 0 \\
\hline & $7 / 13 / 01$ & 0.024 & $<0.1$ & $<0.05$ & 0 \\
\hline & $8 / 21 / 01$ & 0.011 & $<0.1$ & $<0.05$ & 0 \\
\hline \multirow[t]{6}{*}{ Flat Creek in Elk Refuge } & $10 / 6 / 00$ & 0.031 & 0.1 & $<0.05$ & \\
\hline & $3 / 17 / 01$ & 0.061 & 0.14 & $<0.05$ & 0.8 \\
\hline & $5 / 1 / 01$ & 0.018 & $<0.1$ & $<0.05$ & 0.8 \\
\hline & $6 / 20 / 01$ & 0.024 & $<0.1$ & $<0.05$ & 0 \\
\hline & $7 / 13 / 01$ & 0.024 & $<0.1$ & $<0.05$ & 0 \\
\hline & $8 / 21 / 01$ & 0.012 & $<0.1$ & $<0.05$ & 0 \\
\hline \multirow[t]{8}{*}{ Elk Refuge Outlet } & $6 / 16 / 00$ & 0.031 & 0.1 & $<0.05$ & \\
\hline & $8 / 19 / 00$ & 0.0231 & 0.12 & $<0.05$ & \\
\hline & $10 / 6 / 00$ & 0.0522 & 0.1 & $<0.05$ & \\
\hline & $3 / 17 / 01$ & 0.067 & 0.15 & $<0.05$ & 2.1 \\
\hline & $4 / 30 / 01$ & 0.018 & $<0.1$ & $<0.05$ & 0.5 \\
\hline & $6 / 20 / 01$ & 0.033 & $<0 . .1$ & $<0.05$ & 1.3 \\
\hline & $7 / 13 / 01$ & 0.023 & $<0.1$ & $<0.05$ & 0 \\
\hline & $8 / 21 / 01$ & & 0.08 & & \\
\hline
\end{tabular}

